\title{
Impact of body condition on postpartum features in morada nova sheep
}

\section{Impacto da condição corporal sobre o pós-parto em ovelhas morada nova}

\author{
Felipe Brener Bezerra de Oliveira ${ }^{1}$; César Carneiro Linhares Fernandes ${ }^{2}$; \\ Aline Maia Silva ${ }^{3}$; Cleidson Manoel Gomes Silva ${ }^{4}$; \\ Luiz Fernando de Souza Rodrigues ${ }^{5}$; Caroline Pessoa da Silva ${ }^{2}$; Davide Rondina ${ }^{6 *}$
}

\begin{abstract}
This study evaluated the impact of nutritional status of Morada Nova sheep at lambing on the reproductive and productive performance and on the survival of lambs in early weaning system. Nineteen, Morada Nova sheep were assigned to two groups according to body condition score (BCS) at lambing: low BCS $(\mathrm{n}=11)$ and high $\mathrm{BCS}(\mathrm{n}=8)$ with body condition respectively of (mean $\pm \mathrm{SD}) 2.0 \pm 0.3$ e $2.9 \pm 0.1$. From birth until lamb weaning (45 days), sheep were weighed weekly and checked the BCS, loin subcutaneous fat thickness, loin depth, hematological profile, milk composition and production, and every three days, we measured the uterine diameter. Lamb weightings were performed up to one week after weaning (52 days). The lower availability of muscle and fat reserves in the low BCS group negatively affected milk production and consequently performance of suckling lambs. However, the results indicated that the uterine involution process, the reproductive parameters including prolificacy, rate of multiple births, number of white blood cells, milk quality, body weight of lambs at birth and mortality rates were not affected by the body condition. The results allowed to describe the responsiveness to opposite nutritional status of Morada Nova sheep, showing their characteristics of adaptation.
\end{abstract}

Key words: Body condition. Ewes. Milk. Lamb. Uterine involution.

\section{Resumo}

O objetivo do trabalho foi verificar o impacto do estado nutricional de ovelhas Morada Nova ao parto sobre o seu desempenho reprodutivo e produtivo e sobre a sobrevivência de cordeiros em sistema de desmame precoce. Foram utilizadas 19 ovelhas Morada Nova, divididas em dois grupos de acordo com o escore da condição corporal ECC ao parto: grupo ECC baixo $(\mathrm{n}=11)$ e ECC alto $(\mathrm{n}=8)$ com escore médio ( \pm DP) respectivamente de $2.0 \pm 0.3$ e $2.9 \pm 0.1$. A partir do parto até o desmame dos cordeiros (45 dias), as mães foram pesadas semanalmente e verificado o ECC, espessura da gordura subcutânea lombar, profundidade do lombo, perfil hematológico, composição e produção leiteira e a cada três dias

\footnotetext{
${ }^{1}$ Zootecnista, M.e em Ciências Veterinárias, Universidade Estadual do Ceará, UECE, Fortaleza, CE, Brasil. E-mail: felipe.brener@ yahoo.com.br

${ }^{2}$ Discentes do Curso de Doutorado do Programa de Pós-Graduação em Ciências Veterinárias, UECE, Fortaleza, CE, Brasil. E-mail: caancesar@gmail.com; carolpessoasilva@gmail.com

${ }^{3}$ Discente do Curso de Doutorado do Programa de Pós-Graduação em Rede Nordeste Biotecnologia, UECE, Fortaleza, CE, Brasil. E-mail: nine.maia@yahoo.com.br

${ }^{4}$ Prof., Universidade Federal do Piauí, UFPI, Bom Jesus do Piauí, PI, Brasil. E-mail: gomesvet@hotmail.com

5 Prof., Universidade Federal Rural da Amazônia, UFRA, Belém, PA, Brasil. E-mail: luizvet.ufra@gmail.com

${ }^{6}$ Prof., UECE, Fortaleza, CE, Brasil. E-mail: davide.rondina@uece.br

* Author for correspondence
} 
mensurado o diâmetro uterino. Os cordeiros foram pesados até uma semana após o desmame (52 dias). A menor disponibilidade de reservas muscular e adiposa no grupo ECC baixo refletiu negativamente na produção de leite e consequentemente no desempenho dos cordeiros na fase de aleitamento. Todavia os resultados indicaram como o processo de involução uterina, os parâmetros reprodutivos como prolificidade, taxa de partos múltiplos, o número de células brancas, a qualidade do leite, o peso vivo dos cordeiros ao nascer e as taxas de mortalidade não foram afetados pela condição corporal. Em conclusão o conjunto de dados obtidos pelo presente estudo permitiu descrever a capacidade de resposta as condições de diferentes estados nutricionais da raça Morada Nova, evidenciando as suas características de adaptação.

Palavras-chave: Condição corporal. Ovelha. Leite. Cordeiro. Involução uterina.

\section{Introduction}

The production and sale of sheep meat has gained importance during recent decades, assuming an important role in the economy of northeastern Brazil, where more than $50 \%$ of sheep flocks in the country are located (LÔBO et al., 2011). Among the breeds raised in this region, hair sheep are more common and include, among other breeds, the Morada Nova and Santa Inês breeds (GOTTARDI et al., 2014). These animals are well adapted to semi-arid climate conditions, and are starting to play an important role in the lives of people in rural areas (CATUNDA, 2011). The Morada Nova breed continues to be popular among small farmers in northeastern Brazil (LÔBO et al., 2011). Ewes of this breed exhibit favorable reproductive characteristics, such as high prolificacy and good maternal ability (FACÓ et al., 2008).

With the intensification of sheep production systems, there is a need to improve the reproductive efficiency of ewes, thus allowing the production of an increased number of lambs. The choice of breed combined with adequate nutritional and health management is essential for improving growth and reproductive performance in Brazilian sheep farming. In sheep flocks, as with other ruminants, the nutritional status of ewes is directly related to their milk production and is the main source of variation in the performance of lambs during the first weeks of lactation. Accordingly, it is important that the ewe has an adequate nutritional level during pregnancy and lactation, as this factor is closely related to the survival rate and the nutritional history of offspring (FERNANDES et al., 2001). In sheep, low nutritional condition at birth produces negative effects on the reproductive efficiency and productivity of the flock, which negatively affects the breeding interval length and consequently reduces the kilograms of lamb that are weaned per ewe per year (TORREÃO et al, 2008). Postpartum fertility depends on two major events: uterine involution and the start of ovarian cyclicity.

However, there is little information about the reproductive and productive behavior of Morada Nova, and information is lacking concerning the relationship between maternal body condition and survival and development of offspring. This information could contribute to a better understanding of the adaptation cues of this breed, as well as optimize the food and health management in rearing systems. Therefore, the present research investigated the impact of nutritional status at lambing on reproductive and productive response in Morada Nova sheep, as well as the performance of lambs during early weaning.

\section{Material and Methods}

The experiment was conducted at the Agricultural Experimental Farm Dr. Esaú Accioly de Vasconcelos, in the municipality of Guaiúba, Ceará State, belonging to the State University of Ceará (UECE), located at 4'2 23"S and 38 38'14"W, from September to December of 2013. This area, characterized by a constant photoperiod regimen, has a warm, tropical, sub-humid climate with a 
mean annual rainfall and temperature of 904.5 $\mathrm{mm}$ and $26-28^{\circ} \mathrm{C}$, respectively, with two distinct seasons: rainy from February to May and dry from June to January.

Nineteen adult, pluriparous Morada Nova ewes were grouped according to body condition score
(BCS) at lambing (RUSSEL et al., 1969) by a single trained examiner, assigned a score using a 1-5 scale with steps of 0.25 : a group with low BCS, with scores between 1.8 and $2.3(\mathrm{n}=11)$ and a group high $\mathrm{BCS}$, with scores between 2.8 and 3.0 $(\mathrm{n}=8)$. Means for BCS in each group are shown in Table 1.

Table 1. Reproductive and productive parameters of Morada Nova ewes and lambs with opposite (low vs. high) body condition score (BCS) during postpartum period. Values are expressed as mean \pm standard error of the mean.

\begin{tabular}{|c|c|c|c|c|c|c|c|}
\hline \multirow{2}{*}{ Parameters } & \multicolumn{2}{|c|}{ Group } & \multicolumn{5}{|c|}{$\mathrm{P}$ - value } \\
\hline & BCS Low & BCS High & Group & TP & Time & G x TP & Gx T \\
\hline No. of ewes & 11 & 8 & & & & & \\
\hline Parturition body weight, $\mathrm{kg}$ & $26.1 \pm 1.0$ & $34.2 \pm 2.3$ & 0.01 & 0.02 & - & 0.31 & - \\
\hline Parturition BCS & $2.0 \pm 0.1$ & $2.9 \pm 0.1$ & 0.01 & 0.98 & - & 0.80 & - \\
\hline No. of lambs & 16 & 11 & - & - & - & - & - \\
\hline Male / Female, $\%$ & $54.5: 45.5$ & $37.5: 62.5$ & - & - & - & - & - \\
\hline Litter size & $1.4 \pm 0.2$ & $1.4 \pm 0.2$ & 0.96 & 0.01 & - & - & - \\
\hline Twinning rate, $\%(\mathrm{n} / \mathrm{n})$ & $41.7(5 / 11)$ & $42.9(3 / 8)$ & 0.96 & 0.01 & - & - & - \\
\hline Mortality at birth, $\%(\mathrm{n} / \mathrm{n})$ & $18.7(3 / 16)$ & $9.0(1 / 11)$ & 0.84 & 0.32 & - & - & - \\
\hline Mortality at weaning*, \% (n/n) & $33.3(4 / 12)$ & $30.0(3 / 10)$ & 0.68 & 0.05 & - & - & - \\
\hline Mortality post-weaning**, $\%(\mathrm{n} / \mathrm{n})$ & $00.0(0 / 8)$ & $00.0(0 / 7)$ & - & - & - & - & - \\
\hline \multicolumn{8}{|l|}{ Lamb body weight, $\mathrm{kg}$} \\
\hline Birth & $1.6 \pm 0.1$ & $2.0 \pm 0.3$ & 0.01 & 0.01 & - & 0.21 & - \\
\hline Weaning* & $4.6 \pm 0.3$ & $5.6 \pm 0.8$ & 0.01 & 0.01 & 0.01 & 0.01 & 0.99 \\
\hline Post-weaning** & $5.3 \pm 0.3$ & $6.3 \pm 0.7$ & 0.07 & 0.07 & 0.16 & 0.47 & 0.97 \\
\hline Daily weight gain*, g & $65.4 \pm 4.7$ & $80.3 \pm 7.1$ & 0.08 & 0.28 & 0.01 & 0.97 & 0.12 \\
\hline Lamb weaned/ewe & $1.1 \pm 0.1$ & $1.2 \pm 0.2$ & 0.68 & 0.07 & - & - & - \\
\hline Lamb weight at weaning/ewe, $\mathrm{kg}$ & $5.2 \pm 0.3$ & $6.7 \pm 0.6$ & 0.03 & 0.22 & - & 0.87 & - \\
\hline
\end{tabular}

*ANOVA results are referred to interval between birth and weaning; **ANOVA results are referred to interval between weaning and 7 days post-weaning. $\mathrm{TP}=$ type of parturition; $\mathrm{G} \times \mathrm{TP}=$ group vs. type of parturition; $\mathrm{G} \times \mathrm{T}=$ group vs. time.

The diet for all of the animals consisted of chopped elephant grass (Pennisetum purpureum) plus commercial isoenergetic and isoproteic feed (10.6\% CP and 66.8\% TDN), supplied in quantities to satisfy the nutritional requirements of sheep in early lactation (NRC, 2007). The diet was provided twice a day in the early morning and late afternoon, allowing leftovers of $10 \%$. The forage: concentrate ratio was 60:40. Animals were kept in a single collective shelter pen, which was clayed with concrete and measured $8 \mathrm{~m} \times 8 \mathrm{~m}$, meeting animal welfare requirements, and received mineral salt and water ad libitum. The lambs remained with their mothers in a creep feeding weaning system until the 45 days of age.

\section{Uterine involution}

To monitor the uterine involution, we used the methodology of Hayder and Ali (2008), consisting of transrectal ultrasound examinations twice weekly beginning three days after calving. The 
measurement recorded was the largest diameter of the gravid uterine horn. This evaluation was performed until complete involution of the uterine horn occurred, which was defined as no difference in the diameter of the uterine horns on two consecutive examinations.

Real-time ultrasound was performed in B-mode (Shenzhen Mindray Bio-Medical Electronics Co., LTD, China, DP-2200Vet) with a $7.5 \mathrm{MHz}$ linear transducer. Ultrasonographic examinations were performed with females in a stationary position, the rectum was emptied, and the transducer was inserted into the rectum along with carboxymethyl cellulose gel. The transducer was moved in order to find the best image of the uterus, and triplicate images of the uterine horn were recorded. Each of the three images $(1,2,3)$ were analyzed and measured using ImageJ software (Image J, National Institutes of Health, Millersville, USA), which was previously calibrated.

\section{Hematological evaluation}

Blood collections were performed weekly from birth until weaning by venipuncture of the jugular vein using tubes containing EDTA (BD Vacutainer ${ }^{\circledR}$, São Paulo, Brazil). Samples were immediately evaluated in an automated hematological analyzer (Mindray BC VET in 2800, Shenzhen, China), used for sheep, obtaining the following parameters: white blood cell count (WBC), red blood cell count (RBC), hemoglobin count (HGB), hematocrit (HCT), mean corpuscular volume (MCV), mean corpuscular hemoglobin $(\mathrm{MCH})$, mean corpuscular hemoglobin concentration (MCHC), distribution of red cells (RDW), and total platelet count (PLT).

\section{Production and chemical composition of milk}

Production and composition of milk were evaluated once a week, from the third day postpartum until weaning (45 days postpartum). Milk production was estimated using the weighsuckle-weigh technique according to Celi et al. (2008). Briefly, the day prior to the measurement, all lambs were isolated from their mothers at 20.00 $\mathrm{h}$ and returned at $08.00 \mathrm{~h}$ the next day, each lamb was weighed before and after being left to suckle. The feeding periods were $30 \mathrm{~min}$. The weight difference between before and after suckling was recorded as the milk production per ewe and the total production estimated according to the methodology proposed by Alencar et al. (1996). To evaluate the composition, milk samples of $10 \mathrm{~mL}$ were obtained from each ewe before suckling. Milk collection was performed by manual milking, and samples were stored in individual plastic containers and properly identified, according to the rules of hygiene and welfare. Then, the samples were evaluated using automated analysis equipment Lactoscan SL® (Milkotronic LTD, Bulgaria), to determining the following milk components: lipid, protein, lactose, non-fat solids, salts, and $\mathrm{pH}$.

Weight, body condition score, loin depth and loin subcutaneous fat

Weight, body condition score, loin subcutaneous fat thickness, and loin depth were evaluated every 5 days from birth until weaning. Lamb weights were obtained up to one week after weaning (52 days). The thickness of the loin subcutaneous fat (SFLT) and loin depth (LD) were also evaluated using B-mode ultrasound (Shenzhen Mindray Bio-Medical Electronics Co., LTD, China, model DP-2200Vet) with a 5-MHz linear transducer. To measure these parameters, the lambs were kept in a stationary position and the transducer was arranged linearly in the region between the 3rd and 4th lumbar vertebrae (TEIXEIRA et al., 2006). Triplicate images of each structure were recorded and each of the three images $(1,2,3)$ were analyzed and measured using ImageJ software (Image J, 
National Institutes of Health, Millersville, USA), which was previously calibrated.

\section{Statistical analysis}

Body weight, body condition, lamb birth weight and lamb weight at weaning per ewe, data were analyzed using PROC GLM and the factors used in the model for analysis of variance (ANOVA) included group (low body condition score, high body condition score), type of parturition (simple or multiple) and interaction. For lamb weight during weaning, weight during post-weaning, daily weight gain, hematological parameters, and milk traits, the model included group, type of parturition, interval of assessment considered (time), and interactions group vs. type of parturition and group vs. time. For the parameters whose descriptive data were obtained using ultrasound (loin subcutaneous fat thickness, loin depth and uterine diameter), results were analyzed using the GLM procedures for repeated measures analysis of variance (ANOVA). The factors used in the model included group, type of parturition, interval of assessment considered (time) and interactions group vs. type of parturition and group vs. time. Images of the structures recorded $(1,2,3)$ represented the repeated measure. Comparisons between means were determined by Student's t-test. For litter size, twinning rate, mortality variable, and lamb weaned per ewe, the effects of group and type of parturition were analyzed with the Kruskal-Wallis ANOVA test. Comparison between numbers was performed using the chi-squared test.

\section{Results and Discussion}

Sheep in the high BCS group, due to the greater nutritional status, presented with a higher body weight at birth (Table 1), a thicker subcutaneous fat layer over the loin $(4.1 \pm 0.2 \mathrm{~mm}$ vs. $3.4 \pm 0.2$ $\mathrm{mm} ; \mathrm{P}=0.02$ ) (Figure 1b) and thicker loin depth $(13.8 \pm 1.3 \mathrm{~mm}$ vs. $8.3 \mathrm{~mm} \pm 0.6 ; \mathrm{P}=0.0003)$ (Figure 1a).

Figure 1 shows the variation in SFTL and LD values from lambing until weaning. Only the LD showed a significant reduction (Figure 1a) during the experimental period (effect of time). The mobilization of LD muscle mass was more pronounced in the group with a higher nutritional status, especially in animals from a multiple birth (G x TP interaction). On average, at 45 days postpartum, there was a statistically significant loin loss of $10.2 \%$ in the group with high BCS (13.8 \pm $1.3 \mathrm{~mm}$ vs. $11.0 \pm 1.3 \mathrm{~mm} ; \mathrm{P}=0.012)$ compared to $3.8 \%$ in the group with low BCS $(8.3 \pm 0.6 \mathrm{~mm}$ vs. $7.9 \pm 0.6 \mathrm{~mm} ; \mathrm{P}>0.05)$. For the thickness of the SFLT, values at weaning of both groups $(3.3 \pm 0.2$ mm vs. $4.5 \pm 0.5 \mathrm{~mm} ; \mathrm{P}=0.001)$ remained relatively constant $(\mathrm{P}>0.05)$ compared to those values at birth (Figure 1b).

The intense loss of body mass in ewes with a high BCS is the main reason for the increased performance of their lambs (SILVA et al., 2011). During the first weeks postpartum, the female responds to a negative energy balance through the mobilization of fat and muscle tissue to meet the energy demand during milk production (LAGO et al., 2001). Animals from a multiple birth usually have a higher mass (Table 1a), which may explain the significant interaction found for LD between the factor group and the type of parturition. Pinheiro et al. (2014) studied the same ultrasound measurements in Santa Inês ewes at different physiological stages, and observed a significant reduction in LD compared to data at birth and at 30 days postpartum. The same authors also reported no reduction in subcutaneous adipose tissue, which was also confirmed by our data (Figure $1 b$ ). 
Figure 1. Loin depth (A) and subcutaneous fat loin thickness (B) of Morada Nova ewes with opposite (low vs. high) body condition score (BCS) during postpartum period. Values are expressed as mean \pm standard error of the mean.
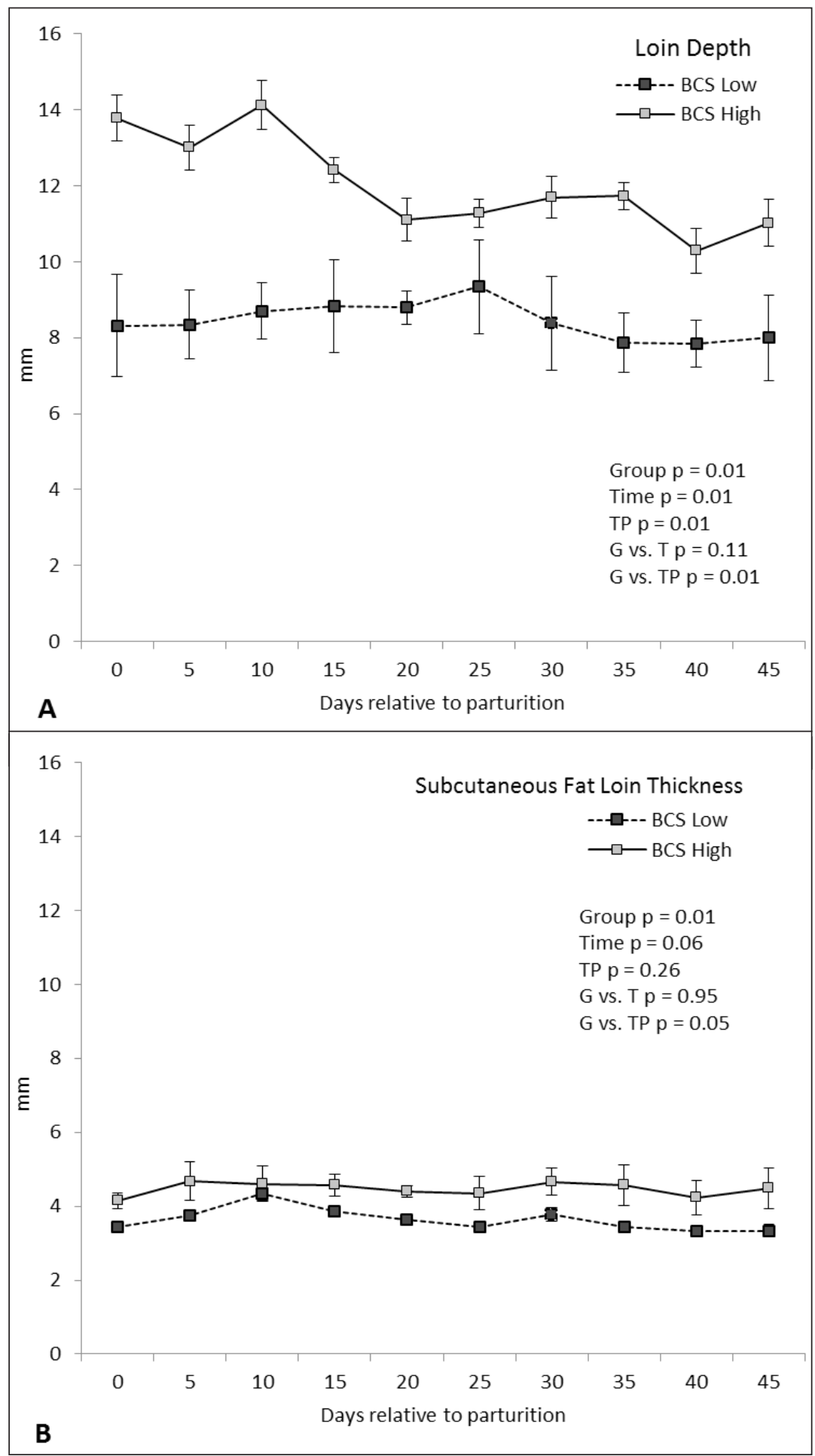
Two reasons probably make the measurement of the lumbar region's adipose tissue with ultrasound less sensitive of LD during the postpartum period. It is well known that mobilization of adipose tissue during a negative energy balance usually originates from the subcutaneous region (CHILLARD et al., 1998). Therefore, similar to other ruminant females, ewes are characterized during postpartum periods with a lean carcass in conformation and finishing. On the other hand, it is important to note that the Morada Nova breed is not characterized by a high deposition of subcutaneous adipose tissue. In an experiment with feedlot lambs, Medeiros et al. (2009) reported a $1.8 \mathrm{~mm}$ thickness, lower is found in breeds that are bred for meat. These same authors observed an increased fat deposition in the omentum, mesentery, and pelvic and kidney regions. This is due to a genetic adaptation to harsh environmental conditions, and is common in other tropical sheep breeds (ERMIAS et al., 2002).

The remarkable difference in nutritional status between the experimental groups did not affect the reproductive performance at lambing (Table 1). The prolificacy was 1.4 , in accordance with the value found with the same breed by Machado et al. (1999) in animals with body condition score of 2 and 3 . The mortality at birth and during the period from birth until weaning (Table 1) was not different between groups. According to Facó et al. (2008), there are few records on mortality rate in the literature for Morada Nova animals, but the values found herein for mortality at weaning ( $\geq 30 \%$ ) are lower than those verified by Mexia et al. (2004) for Santa Inês sheep, who found a $41.9 \%$ mortality rate at 30 days postpartum.

Moreover, in this study, uterine involution was analyzed by regular ultrasound examinations of the uterus and the measurement of its diameter. In sheep, this procedure has proven to be an efficient and adequate method, as it allows real-time monitoring, and gathers important information to predict uterine function postpartum (HAYDER; ALI, 2008; FERNANDES et al., 2013). During the experimental period, the reduction of the uterine lumen (Figure 2b) resulted in a decrease of $0.7 \pm 0.1 \mathrm{~mm} /$ day in both groups. This value was not affected by nutritional status, indicating that uterine involution in the Morada Nova breed is not associated with the energy status at birth. There was also a significant interaction between the group and the type of parturition (Figure 2a) with a larger uterine diameter in animals with multiple births compared to simple births $(23.5 \pm 0.5 \mathrm{~mm}$ vs. $22.6 \pm 0.5 \mathrm{~mm} ; \mathrm{P}=0.01$ ), a value that resulted in a significant difference for the group with high BCS $(24.2 \pm 0.8 \mathrm{~mm}$ vs. $21.9 \pm 0.8 \mathrm{~mm} ; \mathrm{P}=0.01)$. These results were expected as the volume occupied by the fetus increases in sheep with multiple fetuses (FERNANDES et al., 2013). Yet no differences in uterine involution were found between the two types of parturition $(0.7 \pm 0.1 \mathrm{~mm} /$ day vs. $0.6 \pm 0.1$ $\mathrm{mm} /$ day; $\mathrm{P}>0.05)$.

The time required for complete uterine involution in sheep ranges from 17 (HAUSER; BOSTEDT, 2002) to 35 days (ZDUNCZYK et al., 2004). Hauser and Bostedt (2002) analyzed the diameter of the uterine lumen and caruncles during the first 30 days post-partum in German Lend sheep and concluded that involution is completed at approximately day 17 after lambing, and later in animals that have been subjected to obstetric intervention, cesarean delivery, and retention of fetal membranes. In Santa Inês sheep, Nasciutti et al. (2012) evaluated clinical features of uterine involution and determined a complete involution up to 28 days postpartum. Zdunczyk et al. (2004) worked with Polish Longwool ewes and verified that uterine involution is completed in up to 35 days postpartum, and this process is shorter in primiparous than in pluriparous sheep. This is similar to a study developed by Hayder and Ali (2008) in which ewes of the Farafa breed were monitored. 
Figure 2. Uterine diameter (A) and uterine diameter reduction rate (B) during post-partum of Morada Nova ewes with opposite (low vs. high) body condition score (BCS). Values are expressed as mean \pm standard error of the mean.

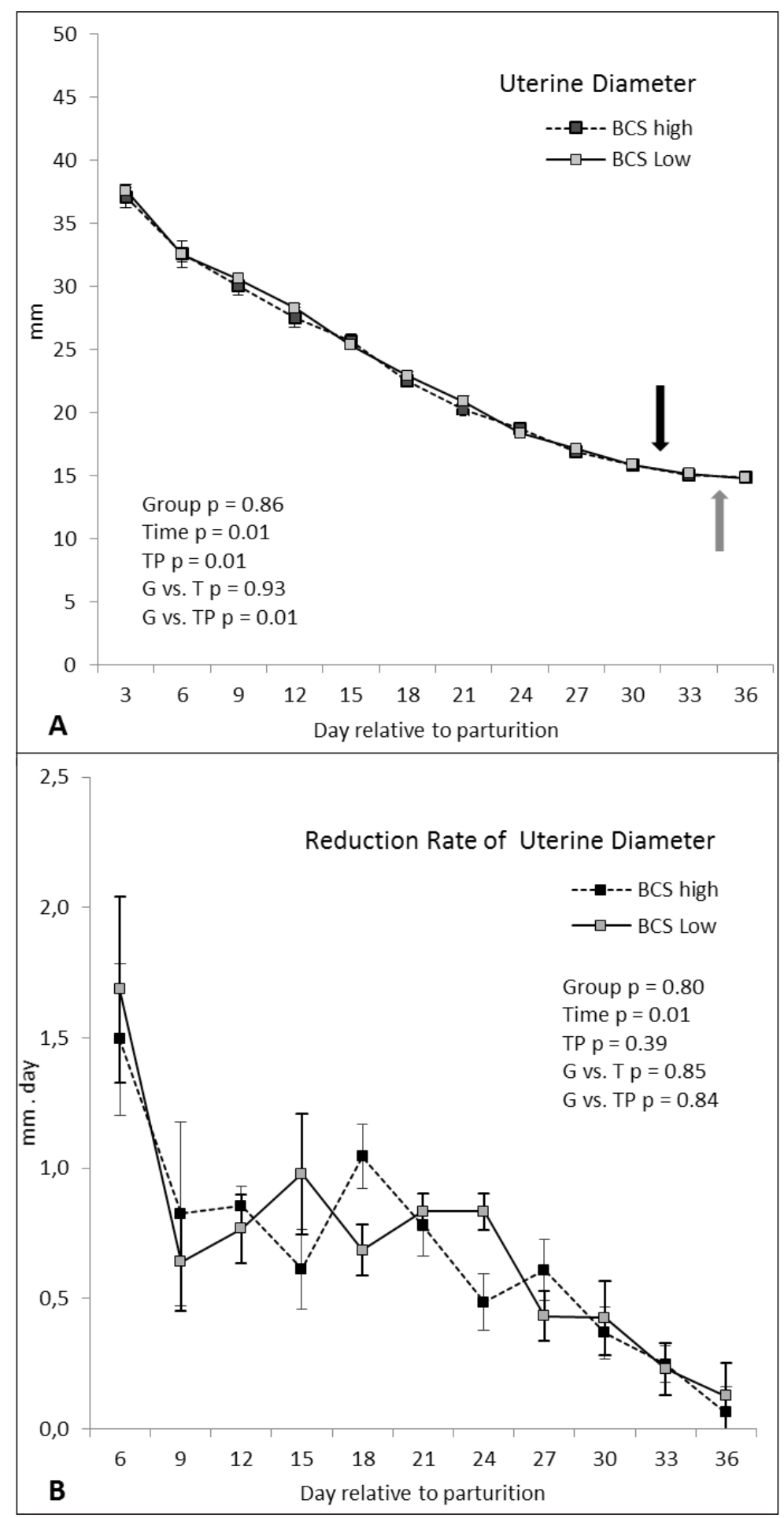

In the present study, we considered that the group with low BCS (Figure 2a), which was defined uterus had completely involuted by the 30th day in as when the rate of uterine diameter reduction was the group with high BCS, and the $33 \mathrm{rd}$ day in the stabilized to below $0.5 \mathrm{~mm} /$ day (Figure $2 \mathrm{~b}$ ). As a 
result, the subsequent values of the uterine lumen were statistically similar.

The effects of uterine infection in ewes during the postpartum period are well known (TZORA et al., 2002); however, parameters such as white blood cell count and other pathophysiological indicators have not been investigated during uterine involution in healthy ewes. It has become fundamental to know the reference values of a complete blood count for healthy animals, as well as the factors causing variations (VIANA et al., 2002). Regarding hematological parameters, body condition did not significantly affect white blood cell count (WBC) (Table 2), as reported by Jalilian and Moeini (2013) in Sanjabi ewes. The blood profile is of utmost importance in assessing the health of a mother during the postpartum period. Usually, the white blood cell count decreases due to the postpartum period and uterine involution, which occurred in this experiment, and the value was higher in animals of multiple births and with low BCS (Table 2). Fernandes et al. (2013), in sheep native to the Brazilian Pantanal, found that the leukocyte profile from the first to the seventh day postpartum presented the most pronounced response in females with twin pregnancies. Also Marino et al. (2014) in South Brazil observed that in crossbred ewes, leukocyte profiles show a significant reduction from parturition to 16 days postpartum. As for the other parameters of the complete blood count, it is worth pointing out the results related to hemoglobin (HGB), red blood cell count (RBC) and hematocrit (HCT), were all higher in the group with a high BCS and multiple births. For Morada Nova ewes during the postpartum period, Bezerra et al. (2013) reported values close to those observed in this study; on average $7.6 \pm$ 1.3 and $9.4 \pm 1.2$ respectively for HGB and RBC. According to El-Sherif and Assad (2001), in a semiarid environment, erythrocytic parameters increase significantly, reaching maximum values at lambing and decreasing after this period, corresponding to the time with a greater metabolic demand (BEZERRA et al., 2013). Brito et al. (2006) in Lacaune ewes and Marino et al. (2014) in crossbred ewes did not find variation in the hematological pattern at 7 and 30 days postpartum, and from parturition to 16 days postpartum, respectively.

Table 2. Hematological parameters of Morada Nova ewes with opposite (low vs. high) body condition score (BCS) during postpartum period. Values are expressed as mean \pm standard error of the mean.

\begin{tabular}{|c|c|c|c|c|c|c|c|}
\hline \multirow{2}{*}{ Parameters } & \multicolumn{2}{|c|}{ Group } & \multicolumn{5}{|c|}{$\mathrm{P}$ - value } \\
\hline & BCS Low & BCS High & Group & $\mathrm{TP}$ & Time & $\mathrm{G} \times \mathrm{TP}$ & $\mathrm{G} \times \mathrm{T}$ \\
\hline No. of ewes & 11 & 8 & & & & & \\
\hline $\mathrm{WBC}, \times 10^{3} / \mu \mathrm{L}$ & $9.1 \pm 0.2$ & $8.5 \pm 0.3$ & 0.41 & 0.04 & 0.01 & 0.01 & 0.93 \\
\hline $\mathrm{RBC}, \times 10^{6} / \mu \mathrm{L}$ & $6.8 \pm 0.1$ & $7.7 \pm 0.2$ & 0.01 & 0.62 & 0.85 & 0.01 & 0.99 \\
\hline $\mathrm{HGB}, \mathrm{g} / \mathrm{dL}$ & $7.1 \pm 0.2$ & $7.9 \pm 0.2$ & 0.01 & 0.15 & 0.51 & 0.01 & 0.99 \\
\hline HCT, \% & $23.2 \pm 0.5$ & $26.4 \pm 0.6$ & 0.01 & 0.63 & 0.87 & 0.01 & 0.99 \\
\hline $\mathrm{MCV}, \mathrm{fL}$ & $34.2 \pm 0.2$ & $33.8 \pm 0.3$ & 0.12 & 0.30 & 0.38 & 0.01 & 0.99 \\
\hline $\mathrm{MCH}, \mathrm{pg}$ & $10.5 \pm 0.1$ & $10.2 \pm 0.1$ & 0.01 & 0.01 & 0.35 & 0.39 & 0.86 \\
\hline $\mathrm{MCHC}, \mathrm{g} / \mathrm{dL}$ & $30.9 \pm 0.1$ & $30.6 \pm 0.2$ & 0.12 & 0.01 & 0.08 & 0.01 & 0.71 \\
\hline RDW, \% & $17.6 \pm 0.5$ & $16.1 \pm 0.1$ & 0.01 & 0.12 & 0.84 & 0.05 & 0.90 \\
\hline PLT, $10^{6} / \mu \mathrm{L}$ & $920.4 \pm 23.6$ & $892.7 \pm 33.6$ & 0.55 & 0.70 & 0.13 & 0.40 & 0.63 \\
\hline
\end{tabular}

$\mathrm{TP}=$ type of parturition; $\mathrm{G} \times \mathrm{TP}=$ group vs. type of parturition; $\mathrm{G} \times \mathrm{T}=$ group vs. time $. \mathrm{WBC}=$ white blood cell count, $\mathrm{RBC}=$ red blood cell count, $\mathrm{HGB}=$ hemoglobin count, $\mathrm{HCT}=$ hematocrit, $\mathrm{MCV}=$ mean corpuscular volume, $\mathrm{MCH}=$ mean corpuscular hemoglobin, $\mathrm{MCHC}=$ mean corpuscular hemoglobin concentration, $\mathrm{RDW}=$ distribution of red cells, PLT = total platelet count. 
The higher nutritional status of the group with high BCS was resulted in a significantly greater amount of milk produced (Table 3), but did not alter its physical and chemical components (Table 3).
Nevertheless, except for lipid content and $\mathrm{pH}$, ewes of multiple births and high BCS showed a positive variation in the parameters of milk production and composition (interaction group $\mathrm{x}$ type of parturition) (Table 3).

Table 3. Evaluation of the milk production and composition of Morada Nova ewes with opposite (low vs. high) body condition score (BCS) during postpartum period. Values are expressed as mean \pm standard error of the mean.

\begin{tabular}{|c|c|c|c|c|c|c|c|}
\hline \multirow{2}{*}{ Parameters } & \multicolumn{2}{|c|}{ Group } & \multicolumn{5}{|c|}{$\mathrm{P}$ - value } \\
\hline & BCS Low & BCS High & Group & TP & Time & Gx TP & $\mathrm{G} \times \mathrm{T}$ \\
\hline No. of ewes & 11 & 8 & & & & & \\
\hline Milk yield, $\mathrm{g}$ & $261.4 \pm 14.4$ & $353.8 \pm 26.1$ & 0.01 & 0.06 & 0.08 & 0.03 & 0.79 \\
\hline \multicolumn{8}{|l|}{ Milk Composition, $\%$} \\
\hline Lipids & $3.5 \pm 0.2$ & $2.9 \pm 0.2$ & 0.22 & 0.38 & 0.43 & 0.27 & 0.69 \\
\hline Protein & $3.8 \pm 0.1$ & $3.8 \pm 0.1$ & 0.43 & 0.01 & 0.85 & 0.01 & 0.92 \\
\hline Solids-non-fat & $10.4 \pm 0.1$ & $10.5 \pm 0.1$ & 0.25 & 0.90 & 0.87 & 0.01 & 0.83 \\
\hline Lactose & $5.6 \pm 0.1$ & $5.7 \pm 0.1$ & 0.20 & 0.01 & 0.55 & 0.01 & 0.90 \\
\hline Salts & $0.8 \pm 0.1$ & $0.8 \pm 0.1$ & 0.13 & 0.03 & 0.69 & 0.01 & 0.96 \\
\hline $\mathrm{pH}$ & $4.5 \pm 0.1$ & $4.5 \pm 0.2$ & 0.70 & 0.02 & 0.01 & 0.08 & 0.40 \\
\hline
\end{tabular}

$\mathrm{TP}=$ type of parturition; $\mathrm{G} \times \mathrm{TP}=$ group vs. type of parturition; $\mathrm{G} \times \mathrm{T}=$ group vs.u time.

The higher production in the group with high BCS was related to the greater possibility of mobilization of body reserves, and therefore greater availability of nutrients to the mammary gland (MENDIZABAL et al., 2011). In general, there are few studies relating production and quality of milk in hair sheep in Brazil. However, it is known that the relative stability in dairy production, also verified by our data in Morada Nova sheep (no significant effect of time), is common in other breeds not that are selected for milk production. Rocha et al. (2013), in the semi-arid region of the Piauí State, observed that Morada Nova sheep exhibited no significant differences in milk production during the suckling phase, when supplemented with 0.5 and $1.5 \%$ concentrate in relation to body weight. Most likely, the lack of the dilution effect in the first month after calving promoted the qualitative parameters to remain constant throughout the experiment (no significant effect of time). The only exception was $\mathrm{pH}$, which had a significant decrease between parturition and postpartum week 4 (effect of time) in both groups. It is possible that increased protein and lactose contents in animals of multiple births (effect of type of parturition) have affected the $\mathrm{pH}$ values, as they are the two main components that affect the milk electrolyte concentration.

The performance of lambs was tested in an early weaning condition using the creep feeding system. At birth, the group with low body condition showed lower lamb weight (Table 1), with a difference of more than $400 \mathrm{~g}$ compared to the group with high BCS. In the latter, the average weight at birth was in accordance with the average values of the breed reported by Fernandes et al. (2001) and Muniz et al. (2010). Birth weight and reduced milk production were responsible for the lower performance of lambs in the group with low BCS (Table 1), weaned at 45 days with significantly lower weight than in the group with high BCS $(6.7 \pm 06 \mathrm{Kg})$ in both types of parturition that were analyzed. Due to 
these observations, animals with nutritional statuses below satisfactory produced a statistically lower weight of lamb weaned per ewe (Table 1).

Fernandes (1992) used a traditional weaning system at 90 days and achieved an average weight of $10.6 \pm 0.7 \mathrm{~kg}$, relatively superior to ours. Meanwhile, for Morada Nova and Dorper lambs at 42 days of life, Torreão et al. (2014) recorded a weight of 7.8 $\mathrm{kg}$, closer to that observed in the present experiment. The viability of the weaning system, beyond the litter performance, also considered the mortality the performance of the first week postweaning. These parameters are the most critical in reducing weaning interval, due to the significant increase in stress to the offspring. Data presented in Table 1 show statistically similar values in both groups and confirm the high responsiveness that distinguishes Morada Nova animals, regardless of nutritional status differences. Facó et al. (2008) considered that the Morada Nova breed is excellent regarding mother ability, able to maintain satisfactory levels of productivity, and fertility, even under the harsh conditions of the semi-arid northeast.

\section{Conclusions}

The evaluation of postpartum features performed in this study allowed us to verify how the Morada Nova breed behaves under differing nutritional statuses. Similar to other species of ruminants, ewes with a lower body condition negatively affected milk production and consequently the performance of lambs. However, our findings demonstrated that in this breed the reproductive response and milk quality was not influenced by a low nutritional status. Nevertheless, reducing the suckling period did not increase mortality, showing the adaptative capabilities of Morada Nova to stressful conditions. Finally, our data indicate that the Morada Nova ewe is characterized by a scarce adipose deposition in the lumbar region, and for this reason it should be used carefully for a measurement of body mass changes during the postpartum period.

\section{Acknowledgments}

The authors thank the technical team of Dr. Esaú Accioly de Vasconcelos Farm for their support and help in handling the animals. The authors would like to thanks CNPq/CAPES through the project Procad/Casadinho (Edital 06/2011), which support the partnership between post-graduation programs from UECE and UFRA.

\section{References}

ALENCAR, M. M.; TULLIO, R. R.; CRUZ, G. M.; OLIVEIRA, M. C. S. Produção de leite da vaca e desenvolvimento do bezerro em gado de corte. Revista Brasileira de Zootecnia, Viçosa, MG, v. 25, n. 1, p. 92101, 1996.

BEZERRA, L. R.; TORREÃO, J. N. C.; MARQUES, C. A. T.; MACHADO, L. P.; ARAÚJO, M. J.; VEIGA, A. M. S. Influência da suplementação concentrada e da categoria animal no hemograma de ovinos da raça Morada Nova. Arquivo Brasileiro de Medicina Veterinária e Zootecnia, Belo Horizonte, v. 65, n. 6, p. 1738-1744, 2013.

BRITO, M. A.; GONZÁLEZ, F. D.; CAMPOS, L. A. R. R.; BARBOSA, L. L. P. R.; BERGMANN, G. Composição do sangue e do leite em ovinos leiteiros do sul do Brasil: variações na gestação e na lactação. Ciência Rural, Santa Maria, v. 36, n. 2, p. 942-948, 2006.

CATUNDA, A. G. V. Avaliação dos parâmetros fisiológicos, metabólicos e reprodutivos de ovelhas deslanadas submetidas à suplementação energética criadas em sistema semi-intensivo no Nordeste do Brasil. 2011. Tese (Doutorado em Reprodução Animal) - Universidade Estadual do Ceará, Fortaleza.

CHILLARD, Y.; BOCQUIER, F.; DOREAU, M. Digestive and metabolic adaptations of ruminants to undernutrition, and consequences on reproduction. Reproduction Nutrition Development, Les Ulis, v. 38, n. 2, p. 131-152, 1998.

CELI, P.; TRANA, A. D.; CLAPS, S. Effests of perinatal nutrition on lactational performance, metabolic and hormonal profiles of dairy goats and respetive kids. Small Ruminant Research, Amsterdam, v. 79, n. 2, p. 129-136, 2008.

EL-SHERIF, M. M.; ASSAD, F. Changes in some blood constituents of Barki ewes during pregnancy and lactation under semi arid conditions. Small Ruminant Research, Amsterdam, v. 40, n. 3, p. 269-277, 2001. 
ERMIAS, E.; YAMI, A.; REGE, J. E. O. Fat deposition in tropical sheep as adaptive attribute to periodic feed flutuaction. Journal of Animal Breeding and Genetics, Malden, v. 119, n. 4, p. 235-246, 2002.

FACÓ, O.; PAIVA, S. R.; ALVES, L. R. N.; LÔBO, R. N. B.; VILLELA, L. C. V. Raça Morada Nova: origem, características e perspectivas. Sobral: Embrapa Caprinos, 2008. 43 p. (Embrapa Caprinos. Documentos, 75).

FERNANDES, A. A. O. Genetic and phenotypic parameter estimates for growth, survival and reproductive traits in Morada Nova hair sheep. 1992. Thesis (Degree of Doctor of Philosophy) - Oklahoma State University, Oklahoma.

FERNANDES, A. A. O.; BUCHANAN, D.; SELAIVEVILLARROEL, A. B. Avaliação de fatores ambientais no desenvolvimento corporal de cordeiros deslanados Morada Nova. Revista Brasileira de Zootecnia, Viçosa, MG, v. 30, n. 5, p. 1460-1465, 2001.

FERNANDES, C. E.; CIGERZA, C. F.; PINTO, G. S.; MIAZI, C.; BARBOSA-FERREIRA, M.; MARTINS, C. F. Parturition characteristics and uterine involution in native sheep from Brazilian pantanal. Ciência Animal Brasileira, Goiânia, v. 14, n. 2, p. 245-252, 2013.

GOTTARDI, F. P.; SOUZA JUNIOR, A.; BARBOSA, Y. G. S.; MARQUES, C. A. T.; BEZERRA, L. R.; ARAÚJO, M. J.; MINGOTI, G. Z.; TORREÃO, J. N. C. Efeito do flushing sobre o desempenho reprodutivo de ovelhas Morada Nova e Santa Inês submetidas à inseminação artificial em tempo fixo. Arquivo Brasileiro de Medicina Veterinária e Zootecnia, Belo Horizonte, v. 66, n. 2, p. 329-338, 2014.

HAYDER, M.; ALI, A. Factors affecting the postpartum uterine involution and luteal function of sheep in the subtropics. Small Ruminant Research, Amsterdam, v. 79, n. 2, p. 174-178, 2008.

HAUSER, B.; BOSTEDT, H. Ultrasonographic observations of the uterine regression in the ewe under different obstetrical conditions. Journal of Veterinary Medicine. A: Physiology Pathology and Clinical Medicine, Malden, v. 49, n. 10, p. 511-516, 2002.

JALILIAN, M. T.; MOEINI, M. M. The effect of body condition score and body weight of Sanjabi ewes on immune system, productive and reproductive performance. Acta Argiculturae Slovenica, Ljubljana, v. 102, n. 2, p. 99-106, 2013.

LAGO, E. P.; PIRES, A. V.; SUSIN, I.; FARIA, V. P.; LAGO, L. A. Efeito da condição corporal ao parto sobre alguns parâmetros do metabolismo energético, produção de leite e incidência de doenças no pós-parto de vacas leiteiras. Revista Brasileira de Zootecnia, Viçosa, MG, v. 30, n. 5, p. 1544-1549, 2001.
LÔBO, R. N. B.; PEREIRA, I. D. C.; FACÓ, O.; MCMANUS, C. M. Economic values for production traits of Morada Nova meat sheep in a pasture based production system in semi-arid Brazil. Small Ruminant Research, Amsterdam, v. 96, n. 2, p. 93-100, 2011.

MACHADO, J. B. B.; FERNANDES, A. A. O.; SELAIVE-VILLARROEL, A. B.; COSTA, A. L.; LIMA, R. N.; LOPES, E. A. Parâmetros reprodutivos de ovinos deslanados Morada Nova e Santa Inês mantidos em pastagem cultivada, no estado do Ceará. Revista Científica de Produção Animal, Teresina, v. 1, n. 2, p. 205-210, 1999.

MARINO, P. C.; SILVA, C. B.; GONZALEZ, S. M.; REWAY, A. P.; ALMEIDA, A. L.; BIANCHINI, T. P.; FERNANDES, T. M.; GOMES, R. G.; LISBOA, J. A. N.; SENEDA, M. M. Biomarcadores fisiológicos de ovelhas (Ovis aries) mestiças durante o periparto. Revista Brasileira de Reprodução Animal, Belo Horizonte, v. 38, n. 3, p. 159-164, 2014.

MENDIZABAL, J. A.; DELFA, R.; ARANA, A.; PURROY, A. Body condition score and fat mobilization as management tools for goats on native pastures. Small Ruminant Research, Amsterdam, v. 98, n. 2, p. 121-127, 2011.

MEDEIROS, G. R.; CARVALHO, F. F. R.; BATISTA, A. M. V.; DUTRA JÚNIOR, W. M.; SANTOS, G. R. A.; ANDRADE, D. K. B. Efeito dos níveis de concentrado sobre as características de carcaça de ovinos Morada Nova em confinamento. Revista Brasileira de Zootecnia, Viçosa, MG, v. 38, n. 4, p. 718-727, 2009.

MEXIA, A. A.; MACEDO, F. A. F.; ALCALDE, C. R.; SAKAGUTI, E. S.; MARTINS, E. N.; ZUNDT, M.; YAMAMOTO, S. M.; MACEDO, R. M. G. Desempenho reprodutivo e produtivo de ovelhas Santa Inês suplementadas em diferentes fases da gestação. Revista Brasileira de Zootecnia, Viçosa, MG, v. 33, n. 3, p. 658667, 2004.

MUNIZ, M. M. M.; SANTOS, T. N. M.; MELO NETO, F. V. O.; QUEIRÓZ, S. S.; FACÓ, O.; LOBO, R. N. B. Desempenho produtivo e reprodutivo de ovinos da raça Morada Nova no semiárido do Ceará. In: CONGRESSO NORDESTINO DE PRODUÇÃO ANIMAL, 6., 2010, Mossoró. Anais... Mossoró: UFERSA, 2010. p. 1-4.

NASCIUTTI, N. R.; TSURUTA, S. A.; OLIVEIRA, R. S. B. R.; BISINOTO, M.; HEADLEY, S. A.; MUNDIM, A. V.; NOLETO, P. G.; SAUT, J. P. E. Perfil metabólico em ovelhas Santa Inês, com baixo escore de condição corporal, no periparto. Boletim de Indústria Animal, Nova Odessa, v. 69, n. 2, p. 137-145, 2012. 
NATIONAL RESEARCH COUNCIL - NRC. Nutrient requirements of small ruminants. National Washington, DC: Academy Press, 2007. 362 p.

PINHEIRO, R. S. B.; JORGE, A. M.; PARIZ, C. M.; YOKOO, M. J. I. Medidas repetidas no tempo realizadas por ultrassom em ovelhas de descarte em diferentes estágios fisiológicos. Semina: Ciências Agrárias, Londrina, v. 35, n. 4, p. 2739-2748, 2014. Suplemento.

ROCHA, A. M.; LIMA, L. A.; TORREÃO, J. N. C.; MARQUES, C. A. T.; MACHADO, L. P.; SARAIVA, L. A. Efeitos da suplementação concentrada sobre o desempenho e metabolismo de ovinos deslanados suplementados no pré e pós-parto. In: CONGRESSO NORDESTINO DE PRODUÇÃO ANIMAL, 8., 2013, Fortaleza. Anais... Fortaleza: Congresso Nordestino de Produção Animal, 2013. p. 1-4.

RUSSEL, A. J. F.; DONEY, J. M.; GUNN, R. G. Subjective assessment of body fat in live sheep. Journal of Agricultural Science, Cambridge, v. 72, n. 3, p. 451454, 1969.

SILVA, L. M.; RONDINA, D.; ARAÚJO, A. A.; SARGENTINI, C.; LIMA, I. M. T.; RODRIGUES, M. R. C.; SOUZA, A. L.; GIORGETTI, A.; OLIVEIRA, C. H. A.; RODRIGUES, F. V. Reproductive responses and progesterone levels of postpartum oestrus synchronization in goats with different body reserves. Italian Journal of Animal Science, Pavia, v. 10, n. 4, p. 160-164, 2011.

TEIXEIRA, A.; MATOS, S.; RODRIGUES, S.; DELFA, R.; CADAVEZ, V. In vivo estimation of lamb carcass composition by real-time ultrasonography. Meat Science, Amsterdam, v. 74, n. 2, p. 289-295, 2006.
TORREÃO, J. N. C.; PIMENTA FILHO, E. C.; MEDEIROS, A. N.; GONZAGA NETO, S.; CATANHO, M. T. J. A.; BARRETO, L. M. G.; SILVA, J. O. Retorno a atividade cíclica reprodutiva em ovelhas da raça Morada Nova submetidas a diferentes níveis de energia metabolizável. Revista Brasileira de Saúde e Produção Animal, Salvador, v. 9, n. 3, p. 621-630, 2008.

TORREÃO, J. N. C.; ROCHA, A. M.; MARQUES, C. A. T.; BEZERRA, L. R.; GOTTARDI, F. P.; ARAÚJO, M. J.; SOUZA JÚNIOR, E. L.; OLIVEIRA, R. L. Concentrate supplementation during pregnancy and lactation of ewes affects the growth rate of lambs from a variety of crosses. Revista Brasileira de Zootecnia, Viçosa, MG, v. 43, ed. 10, p. 544-550, 2014.

TZORA, A.; LEONTIDES, L. S.; AMIRIDIS, G. S.; MANOS, G.; FTHENAKIS, G. C. Bacteriological and epidemiological indinds during examination of the uterine content of ewes with retention of fetal membranes. Theriogenology, Philadelphia, v. 57, n. 7, p. 1809-1817, 2002.

VIANA, R. B.; BIRGEL JUNIOR, E. H.; AYRES, M. C. C.; BIOJONI, F. S. M.; SOUZA, M. C. C.; BIRGEL, E. H. Influência da gestação e do puerpério sobre o leucograma de caprinos da raça Saanen, criados no Estado de São Paulo. Brazilian Journal of Veterinary Research and Animal Science, São Paulo, v. 39, n. 4, p. 196-201, 2002.

ZDUNCZYK, S.; MILEWSKI, S.; BARAŃSKI, W.; JANOWSKI, T.; SZCZEPAŃSKI, W.; JURCZAK, A.; RAŚ, A.; LEŚNIK, M. Postpartum uterine involution in primiparous and pluriparous polish longwool sheep monitored by ultrasonography. Bulletin of the Veterinary Institute in Pulawy, Pulawy, v. 48, n. 3, p. 255-257, 2004. 
